\title{
Power and education
}

\section{Adéla Antlová}

\begin{abstract}
In this paper, we raise the question about the position of education in contemporary society, and we try to give an answer to it. We focus on two words: power and education, and we reflect the connection of these two terms from different points of view. At first we contemplate about the different types of power which can be found at school, second we consider the power of education, and third we seek the ways of making education even more powerful. It is a reflection on the potential of education as well as its limits. We also focus on aims which education has to fulfil.
\end{abstract}

Key words: school education, power, development, aims.

\section{Introduction}

What is the position of education in today's society? Can we still consider school education to be the best way of formal learning? We are to answer these questions in the following paper. Formal education plays an important part in our lives. Nevertheless, its position has to be discussed and evaluated. Either parental or school education is a human construct, and that is why it develops together with the development of society. It is possible that one day the power of education will start to weaken. For example today, there is a thread of growing influence of technologies, which have brought changes in education already.

In the past, the power of education was sometimes underestimated, sometimes overestimated. What do we say about the power of education today? Is it possible for children to develop without education? Our assumption is that a human being pos- 
sesses innate predispositions which direct him or her to his or her development, as the ability to learn is developed in all organisms. The example of so called feral children shows, that human beings are able to survive without education, they will also develop to a certain degree, probably to the extent of what they can observe and imitate. In contrast, Vygotsky pointed out, that a child achieves better results with a little help from adults. If left alone, children would probably develop to a certain extent. However, the majority of them would probably get to a much lower level compared to the level they would reach with the help from adults.

\section{Power in education}

Power is usually considered to be a tool that enables one to control the others, to impose his or her will on others, something that gives us certain superiority, etc. We have to be careful not to consider power only a negative force. For Foucault, power is present in every relationship, and it is a necessary, productive and positive force (Chudý and Neumeister, 2014, 46-47). Foucault (in Chudý and Neumeister, 2014, 46) points out the connection between power and knowledge, and he concluded that knowledge is not neutral in relationship with power but they are productive. That means that knowledge gives an individual certain power, and at the same time power demands the increase in knowledge. In short, the greater the knowledge, the greater the power. The higher knowledge therefore gives teacher a certain power.

Another form of power we can find in education is what Foucault called "shepherd/ pastor power" (in Chudý and Neumeister, 2014, 46-47). This relationship between the dominant and the submissive might be described as the permanent care for an individual as well as the entire herd. The shepherd leads and takes responsibility of the herd, and the herd obeys him in respond. Chudý and Neumeister $(2014,47)$ compare this to the situation at current school, where teachers are in the role of shepherds and their pupils in the role of the herd. Some teachers, nevertheless, try to establish the relationship between them and their students on a more democratic basis (in Chudý and Neumeister, 2014, 49,90). They try to approach to the pupils or students in a friendlier, more equal way. This partnership is broken after not fulfilling the agreement between pupils and teachers, though. Therefore, the teacher's effort to gain the power again breaks through.

But we have to be careful when we connect knowledge and power as in life knowledge does not necessarily mean we will be more powerful. We have to consider what specific knowledge or combination of different pieces of knowledge gives us power in a certain situation. The school situation is even more specific as the call for its democratization and humanization forces teachers to be partners of learners rather than their leaders. This partnership is more natural because knowledge is not an abstract entity, and the teacher cannot possess it and distribute it. He or she as well as their learners 
create knowledge themselves. Therefore, the teacher only helps them in this process while his or her development is not finished yet. Therefore, teachers exceed their learners in some aspects but in some other aspects their students or pupils exceed their teachers. That is why the power of teachers is limited, and this might be the source of problems teachers encounter in their lessons. They overestimate their power or they underestimate the power of their learners ${ }^{1}$. The teacher than tries to change the fact that his student does not accept the submissive role and does not realize he or she has only a little chance of doing it. Some teachers try to become friends with these influential students, and these teachers are more successful in cooperation with the powerful learners as they mutually tolerate each other. The problem is, as Fullan (2013) states, that school "pushes learners and teachers out of school" as they consider this place boring while the world outside (together with technologies) alluring. We should accept the fact that in a democratic society the power of teacher does not span over all of the students unless school is less boring place than the world outside.

In conclusion, the knowledge of the subject might put teachers in the more powerful position when compared to their learners. This knowledge, however, does not necessarily mean that the teacher can use this knowledge successfully to maintain his/ her power because other variables such as personality traits, appearance, communicative and social skills etc. play an important part.

\section{Power of education}

In the previous chapter we dealt with the power as a part of the educational process. Now we are going to reflect the power of education, seen as the effect of education.

Let us get inspired by nature, as Comenius used to do, as nature may supply us with many examples that we can apply in this case. Let us imagine the power of education as sunshine and its energy, which can be either constructive or destructive. When the strength of the rays is too powerful, we have to hide from it in order not to get damaged. On the other hand, when it comes in a moderate intensity, it is life-giving, energizing, healing and comforting. Similarly education, in case it forces some conviction, it leaves deep scars on the soul of a person who is being educated. When it moderately enlightens, its impact will be positive. At the same time, we should consider the power of education as the first impetus which sets in motion the forces bringing a person to his or her growth rather than a force causing sudden and enormous changes in an educated person. Similarly as the first spring rays awaken the forces in the seeds and cause the changes leading to their growth, which is progressive and not sudden.

\footnotetext{
For example, some learners have higher power in some respect than the teacher and therefore, the teacher is helpless in this class. The teacher tries to impose his or her will on the learners, but his position in the class is more submissive than dominant when compared to certain student. The power of the dominant student might come from his or her personality traits, physical strength, his parent's influence, some skills...
} 
The above mentioned example shows us how education can positively affect an individual. That is to awaken the hidden forces and to enlighten. Beside these, there is another source of the power of education. It is its ability to transfer knowledge. Adults or those who consider themselves more advanced in something try to pass their experience on the young. Although Fink (in Strouhal 2013, p. 38) points out that experience is not directly transferable because it is always distorted. And more complex the information we want to transfer, more distorted it must be. Palouš (in Strouhal 2013, p. 39), on the other hand, adds that to transfer the direct knowledge (the knowledge of one person to another person) is not the aim of education because it is not even possible as knowledge advances into new context with every person. The aim of education for Palouš, on the contrary, is to prepare an individual toward the openness to the world and other people.

Bearing in mind the above mentioned with which we agree, we need to highlight that education enables to transfer knowledge, experience. Even though everyone transforms the knowledge, which is coming from the outside, in his own manner, it is still the knowledge which comes from the outside and from human history. Even though, transformed and passed on someone else. Without the ability to suck in information from the outside and to pass it on, our development (the development of humankind) would not be possible. Without the influence of other people or other sources we do not create anything. Education therefore functions as an inspiration, the source of information which must be overcome, in order to develop.

In conclusion, school must be a source of information, or it should help learners find information and help learners process it in a useful way, similarly, as learners do project work nowadays. And the school success should be measured according to quality of work done and not according to quantity of content learned as it is common.

\section{How to make education more powerful?}

Although education is powerful itself, teachers all over the world kept thinking about how to transfer knowledge in the best way possible (to make it even more powerful). Dewey (2001) speaks of learning that comes from experience, which a learner acquires from an activity. This is the way how we obtain true knowledge. There is, however, a difference between learning "for" school and learning from life. The second comes as an inevitable result of our acts, and the former one is reduced and artificial, in comparison to it. Life teaches us every time we have to adapt to changing conditions. This happens almost permanently, and it is especially expressed whenever we have to make a decision and evaluate. For a teacher, this means to provide learners with as many situations which make them decide and evaluate as possible.

We have to emphasize at this point that it is not our aim to criticize practical school activities, i.e. any activity which teachers use to connect theoretical knowledge with 
life. We agree that they deepen knowledge, expand learner's viewpoint, encourage their curiosity, etc. However, it is still something that must be done because a teacher urged them to do it; and therefore, it is far away from a natural activity arising from the current state of a learner's development and needs. Practical education does not guarantee understanding, getting under the surface. This usually happens when we are engaged in an activity personally and when our emotions are involved in it. Tichomirov (in Babaeva et al., 2013, p. 7-8) proved that emotions partake on cognition and play a positive role as they integrate former pieces of knowledge and help an individual construct new personal meaning. The so called "emotional solution" to the problem precedes comprehension and verbalization of an idea. For example, this happens when we have already heard something for so many times that it is fixed in our memory, and after connecting it with a specific situation in which our emotions are involved, we suddenly realize its true meaning. To get under the surface means to know and to feel at the same time; to know the wide theoretical base, the context, and to feel it in connection with our life. To understand the deep meaning is a difficult process, and it takes a lot of time. Therefore, school conditions must be adapted to it. The qualitative learning should replace the quantitative learning; therefore, the content taught at school must be changed as well. School has to select the most important content of every subject and leave out the rest. We consider the most important pieces of knowledge those values and phenomena which are fundamental to human, natural and society's preservation.

The power of education lies in an ability to renew the unity of a person, i.e. the unity of body, mind and spirit, and moreover, our unity with nature, the universe and other people. The unity does not mean to disappear in the crowd. Everyone is a unique being that matters because he or she acts, affects, creates... and by the activity transforms themselves as well as the world outside of him or her, and thus fulfils his or her duty, to fulfil the existence. This activity, mental or physical, is the sense of life. That is why we should consider an education towards activity as an opposite to apathy, indifference, unconcern... another significant aim of education. The young have to be brought up to make decisions and to accept responsibility for them.

\section{Education as hope}

The aim of education (both, school and parental) is to bring up the young in such a way that they will enable nature and human race to thrive. Unlike the recent parasitic way of living, which is conditioned by someone else's detriment. Human welfare is nowadays growing to the detriment of nature. Some nations survive only because other nations are exploited. And this state continues despite (and also because of) the enormous scientific progress. Obviously, there is a gap between scientific and socio-environmental development, which must be overcome. In other words, we are developed enough in 
scientific area, and now we have to concentrate on the development of our harmonious coexistence on this planet (coexistence with other people, other creatures and with inanimate nature).

It is quite understandable (when we imagine what the content of education during last decades was) that scientific progress is more advanced than any other because school concentrated mostly on knowledge transition. We have to make a big change in our thinking. We have to educate the young towards the sustainable development at the first place. Therefore the main aim of education cannot only be to know but also to feel, to get to know the value of nature and society. And this must not be accepted as a momentary, fashionable tool but holistically, systematically and purposefully. To put in harmony our industrialized society and nature is one of the biggest tasks of this and next generations. We have to adjust our development to the laws of nature so that the future development of humankind does not destroy the rest of the planet.

People not only have to renew the connection with nature, they also have to renew the connection with other people. That means to treat them as in "love thy neighbour", i. e. to make an effort to get to know people around you, to build up the relationship on appreciation of others for their virtues, not to take them as your rivals and not to judge them because of their mistakes. On the contrary, one has to help others uncover and overcome their faults and thus help him or her in their personal growth.

To get to know the value of nature means to love her as our mother. We would be condemned to death without her. If we do not systematically cultivate the respect and love for nature in children, it will sooner or later give up the fight against our damaging conduct. Not nature as a whole, because organisms are very successful to find any possible way how to adapt to almost any conditions, but nature in its biodiversity, which has already been dying out. We take our surrounding environment for granted. We will realise how fragile it is if we move to live in a big city where nature almost gave up. Many people have already been fighting for preservation of biodiversity. Nevertheless, there are plenty of those who think it is not their concern. For example we can see how little attention is devoted to current disastrous fires in Indonesia. It is only another example of the superiority of money above nature. In conclusion, it is the main duty of every parent and every teacher to awake in the young the humility, respect and love for nature.

\section{Conclusion}

It is probable that formal education such as we know it today will change fundamentally one day. School develops together with the development of society and it adapts to its changes. The changes in education must follow the needs of the planet. The young must be therefore led to a better cooperation, coexistence with other people and with nature. Formal education is the best way how to affect whole generation which must 
be taught new values and, it must focus on emotions equally instead of former focus on knowledge.

The connection between the words power and education can be thought of from different perspectives. Knowledge gives an individual certain power, as it puts him/ her in a more advantageous position (i.e. power to make better decisions and better choices according to certain knowledge). In school environment, knowledge (any kind of knowledge i.e. of a subject, of a learner, of method etc.) gives a teacher a certain degree of power (e.g. he can choose a better method for the distribution of certain knowledge). However, it does not secure teacher success, as there are other variables which enter the teacher-learner relationship. Many problems come from the fact that a teacher does not realize and admit that learners also possess a certain degree of power, which might in some aspects be even more influential than teacher's.

The interference in human development should never be violent. It must not force children into anything that would damage their spirit. On the other hand, children must be taught what is necessary for the world's and society's survival. Besides, education must contribute to an individual's growth. Education should inspire, offer, show, make learners process this source of information and transform it in his/her own way.

\section{References}

Fullan, M. (2013). The New Pedagogy: Students and Teachers as Learning Partners. In: LEARNing Landskapes. [online]. [cit. 18. 9. 2015] Quebec. Available at: http://www.learninglandscapes. ca/images/documents/ll-no12/fullan.pdf

Babaeva, Y. D. (2013). Contribution of Oleg K. Tikhomirov to the Methodology, Theory and Experimental Practice of Psychology. In: Psychology in Russia. [online]. [cit. 18. 7. 2015] Moscow: Lomonosov Moscow State University. available at: http://psychologyinrussia.com/volumes/ pdf/2013_4/2013_4_4-23.Pdf

Dewey, J. (2001). Democracy and Education. In A Penn State Electronic Classics Series Publication [online]. [cit. 1. 7. 2015] available at: http://www2.hn.psu.edu/faculty/jmanis/johndewey.htm.

Chudý, Š. \& Neumeister, P. (2014). Začínajúci učitel'a zvládananie disciplíny v kontexte 2. stupňa základnej školy. Brno: Paido.

Strouhal, M. (2013) Teorie výchovy. K vybraným problémům a perspektivám jedné pedagogické disciplíny. Praha: Grada.

\section{Contact:}

Mgr. Adéla Antlová

ÚPSS PdF Palacký University in Olomouc

Žižkovo nám. 5, CZ-771 40 Olomouc

E-mail: adela.antlova01@upol.cz 